\title{
Ethnic School Segregation Exists: Possibilities for Counteracting Measures
}

\author{
Dorothee Peters ${ }^{*}, 1$ and George Muskens ${ }^{2}$
}

\author{
${ }^{I}$ National Knowledge Centre Mixed Schools, The Netherlands; Academic Medical Centre/University of Amsterdam, The \\ Netherlands \\ ${ }^{2}$ DOCA Bureaus, Kerkstraat 27, NL-4664, BN, Lepelstraat, The Netherlands
}

\begin{abstract}
Ethnic school segregation exists. In The Netherlands, in other countries of Europe and in other parts of the world. It seems that it is partly caused by the freedom of parents to choose a school for their children. The result is a growing segregation between children with different cultural backgrounds. Proof is found for a white flight in The Netherlands, Denmark and the United Kingdom [1]. Countries, once they have acknowledged this development, are faced with a scope of possibilities for measures. In The Netherlands several initiatives are started and some measures were implemented to prevent primary education from ethnic segregation or to diminish it, when occurring. Most measures are parental initiatives or local dispersion plans. In this paper we will discuss some promising recent Dutch case studies of local parental initiatives and local dispersion,
\end{abstract}

Keywords: Ethnic segregation, desegregation measures, freedom of education, inclusion, priority education.

\section{INTRODUCTION}

Central issue of this article is the free choice of parents for a suitable school for their children as a practice that is causing ethnic school segregation, not as its intended effect but as its mostly unintended side-effect, as well as Dutch policy lines to attack (negative effects of) this segregation. Measures to reduce ethnic school segregation is part of priority education. "It [i.e. the frame of priority education (authors)] offered a more or less coherent frame for means and measures to compensate schools and pupils for deficiencies and/or discrimination. Without these priority means and measures, deficient and/or discriminated pupils would run the risk of failing in their educational career and to be excluded from schools for further education [2]".

The second paragraph of this paper, consists of a brief introduction with regard to ethnic school segregation in The Netherlands. Paragraph three introduces the freedom of school choice. The fourth paragraph introduces several policy lines from The Netherlands in order to prevent primary education from ethnic segregation or to reduce it, when occurring, followed by the conclusion in paragraph five.

\section{ETHNIC SCHOOL SEGREGATION}

Ethnic school segregation exists. In Dutch public debate it is often referred to as the distinction between 'black schools' and 'white schools'. A so-called 'black school' is a school with many pupils of immigrant descent - mainly Turkish and Moroccan - and a 'white school' is predominantly catering for the pupils of native descent. Since the early nineties, large numbers of 'white parents'

*Address correspondence to this author at the Academic Medical Centre/University of Amsterdam, The Netherlands; Tel: 003120-5668204;

E-mail: d.t.peters@amc.uva.nl have stopped to register their children at 'black schools' (in the making) in their neighbourhood. In combination with high numbers of 'white migration' from 'black neighbourhoods' in the major cities, this trend is known as 'white flight'. 'Black schools' are often regarded as weak schools with low performances, independent of the actual achievement figures. Most local policy makers define 'black schools' and 'white schools' as a problem when schools are 'too black' or 'too white' compared to the neighbourhood where the school is located. This means that the percentage of immigrant or indigenous pupils in a school has been compared with the percentage of immigrant or indigenous pupils who live in the district of the school. "A school is 'too black' respectively 'too white' if there is a major difference between these two percentages. The relative criterion shows the degree of an unequal dispersion of immigrant and indigenous pupils over a district or a city. This degree is called ethnic school segregation degree [2]". Although this started as a problem in the largest cities, smaller cities and some villages also have to deal with it. It regards, among others, small cities in industrial zones, where large numbers of 'guest workers' have settled since the nineteen-sixties and -seventies, as well as rural places with major asylum centres.

In The Netherlands 1,553 million pupils visited one of the 7.546 primary schools in the school year 2008/2009 [3]. According to segregation levels, data is available of schools in the 38 largest cities of The Netherlands. The ethnic school segregation degree has been determined by Wolfgram [4]: $p$. 9. He compared the school populations with the neighbourhood populations in the 38 largest cities of The Netherlands. On average, the school population of 63 percent of the schools in these cities is reflecting the population of their neighbourhood rather well. 17 Percent is too 'white', compared to the neighbourhood and 20 percent is too 'black'. The largest cities of The Netherlands (The Hague, Utrecht, Amsterdam and Rotterdam) show a segregation degree of at least 40 percent. This means that less than 60 
percent of school population is reflecting the population of the neighbourhood. Wolfgram proved that the 'whiter' and the more 'Dutch' the inhabitants of a neighbourhood are, the more schools are reflecting their neighbourhood [4]. Therefore, cities with high numbers of immigrant inhabitants show a higher degree of segregation.

In public and academic debate, the two main arguments against ethnic school segregation are related to the quality of education and the integration issue or citizenship education. 'Black schools' should undermine the learning performances of pupils, because of deficiency in language skills and the lack of presence of indigenous classmates to learn from. Research results show inconsistencies according to this subject. For example, Dutch studies such as [5-7] show that this fear is not completely justified, as a reasonable portion of the 'black schools' improved the language and arithmetic skills of the pupils very well, compared to the performance of the 'white schools', e.g. in relation to the priority measures and budgets they could rely upon. Moreover, they showed that immigrant pupils do not necessary perform better in 'white schools' than in 'black schools' [8]. In contrast, Heckmann showed evidence for the theory that segregation undermines learning performances by mentioning the peer effects [1]. He justified his statement with several references, namely [9-13]. Driessen et al. showed the effect of different kinds of schools on the performance of the pupils. They found that the social-ethnic composition of a school did affect the language performance and did slightly affect the arithmetic performance [14].

Another argument against ethnic segregation regards the lack of inter-ethnic contact, inter-cultural learning and grass-root multiculturalism [2, 15]. According to the "contact hypotheses' of Allport long-lasting contact should result in decreasing ethnic prejudices and it should stimulate reciprocal ethnic appreciation [16]. In this case 'mixed schools' would be the best condition to improve contact between immigrant and indigenous pupils. However, Bakker et al. did not find convincing proof for this hypothesis [17]. This problem remains an issue of debate.

Spatial segregation (neighbourhood, housing) is another important factor related to ethnic school segregation: while poor people are concentrated in cheap housing areas, the number of immigrant people among the poor people in the cities is high. Furthermore, education laws and regulations contribute to segregation. The former Jim Crow laws - that authorized de jure segregation in the South of the United States between 1876 and 1965 - are an example of this. “... segregation in public education had powerfully buttressed Jim Crow, the state-sponsored, constitutionally protected system of racial discrimination and segregation that deliberately disadvantaged more than 10 million black people in the South and parts of the border states [18]". Another cause which has been distinguished in The Netherlands, is the way schools promote themselves: some schools are apparently better for indigenous pupils from affluent families, while others make themselves attractive for immigrant pupils (e.g. to attract priority measures and budgets) or have become the wastebasket of the local educational market. According to Pas and Peters these mechanisms have reinforced the segregation of 'black schools' and 'white schools' [19]. This situation is based upon the freedom parents have to choose any school they want, as will be argued in the next paragraph. According to Karsten et al. parents have different motives to choose a school, e.g. the distance between home and school, the education level, differentiation within classes, religion and identification with the school [20]. The latter motive is an explanation of the 'white flight', referring to the mechanism that parents withdraw their children from a school because it has a large population of immigrant pupils or the fact that parents avoid such a school in the first place [19]. Heckmann indicates three main factors which cause the 'white flight': "the obligation or freedom of choice for attending particular schools in certain residential districts", "the definition of school districts" and "opportunities or restrictions to attend private-sector schools [1]". He also shows that evidence has been found for the occurrence of 'white flight' in Denmark, The Netherlands and the United Kingdom [1].

\section{FREEDOM OF CHOICE}

In The Netherlands, the freedom of choice is a result of the constitutional reform of 1917 and the so-called pillarisation since the early Twentieth Century. The pillarisation is a fragmentation in society, based on religion. Since a change of the constitution in 1848 this segmentation was introduced in education as well, because the constitution allowed to set up schools based on a religion. Up to the constitution of 1917, these religion-based schools had to be financed privately. Since 1917, financial conditions for public-authority and private-sector schools were equalised [21]. Groups of e.g. parents received the constitutional right to establish and maintain their own private-sector schools and other educational institutions (within the limits of certain conditions and rules with regard to quality and numbers). Such private-sector schools were to be financed from the state budget under the same conditions as public-authority schools and educational institutions [2]. In 1968, i.e. 50 years later, Lijphart showed the effects of educational freedom as settled in the Dutch constitution: [translated from Dutch] "Approximately half a century ago [1917; DP] more than $3 / 4$ of all primary school pupils visited public-authority schools. In 1957 the situation was almost the opposite. Only 28 percent of the pupils visited public-authority primary schools and 72 percent visited private-sector primary schools." [22]. According to Miedema and CBS (Statistics Netherlands) 43 percent of these pupils visited a Catholic primary school, 27 percent a Protestant-Christian primary school and 2 percent went to a different kind of privatesector school $[23,24]$. At that time the private-sector schools were visited by pupils with the same religious background. Although since the fifties, most native Dutch families had loosened their religious ties and affiliations, most pupils visit religious based private-sector primary schools. In 2007 approximately 33 percent of the 1.663 .500 pupils visit a public-authority primary school and about 66 percent a private-sector primary school [25]. The majority of the private-sector primary schools are Catholic or ProtestantChristian schools. In addition, there are also Muslim, Jewish and Hindu schools. The distribution over the schools of pupils with a specific religious background is not as strict as before: pupils with a liberal background (former publicauthority school visitors) visit private-sector schools and religious pupils visit schools from another religion, or a 
public-authority school. This means that parents have given another interpretation to their freedom of choice. Laemers concluded that there is a disintegration of the religious foundation of the mainstream religious schools on the one hand and on the other hand the few new built schools might have a strict religious foundation (Islamic, evangelical and Hinduistic) [26]. ${ }^{1}$

As mentioned earlier, Dutch parents can choose a suitable school for their children; they have a freedom of choice, which is derived from the constitution. This provides them a powerful position in the debate on ethnic school segregation. Measures imposed from above can hardly be executed without the co-operation of parents. Because of the freedom of choice they can choose any school they want, apart from some limited restrictions (admission standards, accessibility and rules for pupil transport) [26]. As Rutten and Peters stated, they hold the key to a successful desegregation policy. Rutten and Peters, and Peters showed that parents are a decisive actor in the local policy field and a necessary partner for all other actors [27, 28].

According to article 23 of the Dutch Constitution, the government cannot interfere with the parental school choice. But this does not mean that free school choice is a fundamental right laid down in the Constitution or international treaties [26]. The constitution restricts the role of the government and does not restrict or mention the role of other actors. This restriction of the government regards three major issues [2]. These issues are:

- $\quad$ To guarantee education for all children and pupils and to establish schools under its own authority or that of municipalities for everyone, whenever and where-ever necessary,

- To set rules for the establishment of private schools, with regard to the minimal number of pupils that is required, and with regard to the quality of education, and

- To guarantee equal financial conditions for public schools and private schools that are all fully financed by the state.

For a long time, the arrangements in The Netherlands regarding autonomy of schools and the parental freedom of school choice were rather unique in Europe. But more countries in Europe have introduced some form of freedom of school choice.

\section{POLICY AND MEASURES IN THE NETHERLANDS}

When countries recognize the mechanisms mentioned in this paper, what are the possible actions to reverse this motion? In The Netherlands, several initiatives and measures have been taken. A selection of these will be elaborated in this paragraph.

\subsection{Policy Framework}

For many years, desegregation measures (aimed at meeting pupils with several kinds of cultural backgrounds)

\footnotetext{
${ }^{1}$ In parallel, most public-authority schools have been 'privatised' in the past decade. They are now governed at arm-length distance of the municipal authorities.
}

were locally initiated in a few Dutch municipalities which were confronted with a certain level of ethnic school segregation. The national government interpreted the quality of education solely as learning achievement and tried to invest in better achievement of so called 'black schools' by means of priority measures in relation to social, economic and ethnic inequities (in Dutch: onderwijsachterstandenbeleid). Some 'black schools' do invest solely in best achievements possible. Although research has not been done yet, it could be possible that most 'black schools' which do quite well in achievement scores prefer not to desegregate and invest in teaching migrant pupils. In the next paragraphs we will elaborate one of such a case.

The desegregation measures in the municipalities can be distinguished as measures imposed from above (stated by the local government) or as initiatives arising bottom-up (from 'grassroot' society). A precondition for measures imposed from above is often a self-imposed contract (convenant) between the municipality and the school boards. Such a contract is self-imposed because according to the Dutch constitution, schools cannot be forced to take action against 'white flight' or other mechanisms and trends of ethnic school segregation. And as mentioned before, parents have an important role in the attack of school segregation. The cases in the next paragraph will confirm this.

Recently, the national government has given attention to desegregation measures. In their paper on parental choice in The Netherlands Ladd, Fiske and Ruijs say that with their commitment to parental choice and school autonomy the Dutch accept a "new form of segregation - based on levels of disadvantage rather than religion - (...)" [29]. But they also consider that since some years segregation of disadvantaged pupils has now become a salient issue in The Netherlands. Three factors should help to explain this change [29]:

- Influx of low-skilled and poorly educated nonwestern immigrants;

- Secularization of society developed a consumer mindset by parents in the selection of schools; and

- Political considerations after the attacks on the Twin Towers in the United States on September 11, 2001.

The coalition agreement of the Dutch Cabinet, concluded in 2007 between Christian democrats and social democrats, stated that schools have to use fixed moments of registration as a measure to reduce ethnic school segregation. Due to an inquiry of primary schools of Regioplan [30], the complexity of the problems and the unclear effects of fixed moments of registration, the minister of education decided to fund a scheme for further desegregation pilot projects. The testing of fixed registration is part of some pilots. The purpose of the pilots is to investigate the best desegregation measures by testing several measures in practice. In 2008, seven municipalities started their pilot. They were supported by the National Knowledge Centre Mixed Schools. After one year, four municipalities joined the scheme. In the second year, seven other municipalities started as a pilot to. The milestones of the several pilots are [31], for example: fixed moments of registration, double waiting lists, agreements with schools on their registration policy, monitoring of the results and further development of the concept 'friendship 
schools'. The pilots are monitored by an independent research unit. The results are expected in 2012.

In the next subparagraphs, we will give a brief introduction of cases with regard to best achievement, registration policies, quota and parental initiatives.

\section{2. 'Zoned Access Rules' in Tiel}

In terms of school choice many native parents living in mixed city districts appeared to be inclined to register their children at popular 'white' schools in other parts of the city. This process had led to a rather obvious ethnic segregation in Tiel, particularly in primary education: some schools were much more 'black' than the population in the surrounding district and some were too 'white' in this respect. To realize the goal of desegregation, the school boards in Tiel formed and implemented their natural recruitment zones scheme. In each zone there is a Catholic, Protestant and a public school. So, according to the boards and the BCP, parents would have sufficient opportunities to choose a school in relation to their freedom of education. Children should go to a school in the zone they live in. This means that schools would not be allowed to admit children from other zones. In case of admittance against this rule, the admitting school would have to explain the scheme and aims to the parents. Then, they should advise them to register their child at a school in the recruitment zone they live in. Although not all the headmasters agreed with this line of action (they were afraid to of losing children, and becoming a smaller school), they promised their board to carry it out appropriately. But they cannot be obliged to do this, in relation to the constitutional and legal framework with regard to school choice. The case of Tiel appears to prove that, even under the condition of a high freedom of choice for schools and parents, there are opportunities for desegregation schemes. This success was enhanced and fostered by:

- $\quad$ The mutual agreement between the local actors - i.e. school boards, schools, parents and municipality,

- $\quad$ No fear of discrimination, and

- A high level of parents' participation.

\subsection{The Nymegen 'Gambling Machine'}

To attack the lopsided growth between advantaged and disadvantaged pupils, the municipality and the school boards implemented a type of a natural recruitment zones policy. The goals are a reduction of the distinction between advantaged and disadvantaged schools, a reinforcement of the relation between the schools and their neighbourhood and a reduction from the number of parents, who are driving their children by car through the city (bringing them to school at the other site of the city instead of a school in their neighbourhood). An important appointment between the municipality and the school boards was the promise of the municipality to invest in a desegregation policy for at least four years.

Nijmegen is one of the pilots in the national policy scheme. This pilot regards a centralised application system for new pupils in primary education with rules about capping percentages of advantaged and disadvantaged pupils per school. It regulates the influence of parental choices for a school. All school boards and every school joins the pilot.
All of this is on a voluntary basis, which means it is a fragile point in the arrangement as a whole. The idea of the recruitment zone policy in Nijmegen is to give more opportunities to disadvantaged pupils to go to a popular school. The intention is to give fair chances to both advantaged and disadvantaged pupils to visit a school in the neighbourhood.

The centralised application system of new pupils is the main instrument of the desegregation policy of Nijmegen. Parents have to make an application through the newly built website www.schoolwijzernijmegen.nl by selecting at least three up to six schools of preference. The municipality and the school boards arranged the following rules of priority [32]:

1. Brothers and sisters will be first to be assigned to the same school,

2. Children who live in the nearest surrounding of the school get the second priority,

3. Remaining applications (out of this group, children who give a positive contribution to the division of $30 \%$ disadvantaged and $70 \%$ advantaged pupils in a classroom will be assigned).

This policy will introduce a 'gambling machine' or 'lottery' in school enrolment: parents put something (information about the pupil accompanied by school preferences) in a machine (the pc) and something (a school) comes out [33]. For parents it might feel like they are lucky, if they can register their child at the school of their first preference. Intentionally, Nijmegen received major publicity with this policy, followed by many reactions, some positive and some negative. The policymakers in Nijmegen are not afraid of negative comments. Although several lawyers told them that this policy might be in line with the freedom of education, they are not sure about it. Parents are still free in choosing a school for their children, but this choice is a bit restricted because of the application rules.

\subsection{Parental Initiative in Amsterdam}

The current discussion on desegregation of the Dutch education more or less started with a successful parental initiative in Amsterdam. Since this initiative several initiatives have been started in Dutch cities, some gained success and 'mixed' the school, others did not.

In 2002, two native Dutch middle class neighbours wanted to undertake action, because they found the distinction between immigrant and native Dutch in De Baarsjes undesirable. They decided to register their children at the nearest primary school. This was a black school with $75 \%$ pupils of immigrant descent. It was located next door in their street. The school was to be ranked as a 'quality school' in relation to the achievements of its pupils and the assessment of the educational inspectorate. So, the two parents wondered why other native Dutch parents brought their children to other, i.e. white schools in other parts of the city. The neighbourhood around the school is ethnically and culturally mixed, which gives an excellent opportunity to create a mixed school. The two parents and the school thought this to be important for the children and their development. They were to become acquainted with different ethnic backgrounds and cultural lifestyles. And for 
all parents, it would also create an opportunity for meeting each other. So the school and the 'initiative-parents' decided to recruit of a considerable number of native Dutch children and so to transform a black school into a mixed one.

The two parents started their initiative in 2002 by registering their children at primary school in their neighbourhood (at that moment a so called black school, situated in a mixed neighbourhood) and proposing actions towards mixing the school population. The parents distributed leaflets on the initiative and together with the school they organized an informative meeting for parents in the neighbourhood. The school arranged attractive changes of the school curriculum and invested in the physical appearance and the maintenance of the school building. At strategically chosen occasions, the school arranged publicity and presented itself as a school of interest. This is a process continuing until today. Three years after the start of the activities, the lowest grades showed a 'mixed population' of pupils (50 - 50 percent). Nowadays, all grades show comparable percentages.

\subsection{Best Achievement at Primary School Mozaïek}

The school is not focussed on the issue of race and difference, although it may refer to the deep cultural divide in Dutch working class districts. The school is focussed on the performance of its pupils in basic skills as needed for further education and society, and at realising the highest gains in this respect during the eight years of primary education. The measurable performance at this point is obvious and remarkable. Since years, the average scores of the pupils for their final test with regard basic skills in language and arithmetic skills were on or beyond the local and national average. The gain from an obvious deficient position at early childhood up to that point is very remarkable. Most schools did not succeed to reach an average score beyond expectation and many even showed a score below expectation. At this school the scores were clearly and significantly beyond expectation. Therefore, the school is willing and able to advise a major part of its pupils to proceed to the upper streams and tracks of secondary education. The usual pattern is the other way around, namely that even the possibly talented boys and girls from 'black' primary schools were to proceed at the lower streams and tracks of secondary education and vocational training. The school could rely on additional funding on behalf of the weight rules as well as other funds for priority education. So, the conclusion should be in favour of priority measures as applied at the Mozaiek school.

\section{CONCLUSION}

In this paper a possible consequence of the parental freedom of school choice is explained: the arise of ethnic school segregation. Schools have a choice in the way they deal with ethnic school segregation. They can focus not on race and difference, but solely on the best achievement of their pupils. Or they can also be aware of aspects like integration and citizenship and try to realize an ethnically mixed school population. As an introduction to Dutch desegregation measures, this paper elaborated several cases regarding this last option. In this paragraph the main focus is on the conditions under which these measures might be successful.
- For desegregation measures, the necessary actors are: municipality, school boards, schools and parents.

- In order to prevent the creation of so-called 'save heavens' for parents who do not want to be involved in desegregation policy (e.g. want to bring their child to a 'white school'), every school board and every school should participate in desegregation measures.

- $\quad$ Actors have to trust each other. They must be sure that every school will commit to the agreements on dispersion of pupils over the schools.

- In order to reach the policy goals, parents have to choose a school in the way that fits into the desegregation policy ${ }^{2}$. They make the final decision about the school they want to bring their child to. So, it appears that parents hold the key to policy success. This is a consequence of the (constitutional) freedom of education.

- The neighbourhood conditions have to require desegregation measures, such as an ethnically mixed neighbourhoods with sufficient numbers of indigenous as well as immigrant pupils.

- In general, desegregation measures should respect the freedom of choice as guaranteed by the interpretation of the national constitutions and are to enforced without strict obligations of the actors. Actors cannot be forced to commitment to these measures. They have to agree with the goal of the policy and its measures. If not, they do not have to participate. Therefore, the measure may need a targeted information campaign on behalf of e.g. national and local authorities, directed towards actors who appear to fear to loss their constitutional rights, who hesitate to show the commitment as requested and who continue to find refuge in their 'safe heaven'.

As mentioned before, these conditions for success were assessed in the Dutch situation and the Dutch legislation. But the conditions related to the free school choice of parents are important for other European countries, which introduced some form of parental freedom of choice. Parents have to be informed and tempted not to choose a school on prevalent ethnic prejudices.

\section{ABOUT THE AUTHORS}

Dorothee Peters MSc. is a researcher in the field of inclusion, exclusion and education, with ethnic-socio school segregation as main focus. She wrote the chapter on priority education and assisted Dr. Muskens with his chapters of the Dutch study on inclusion and education. Currently, she works as PhD-student for the department of Public Health of the Academic Medical Centre/University of Amsterdam.

Dr. Muskens is a senior researcher and project coordinator in the field of ethnic relations. For the Dutch study on inclusion and education he was responsible for the chapters on early school leaving, inclusive education, bullying and harassment, minority education and teacher

\footnotetext{
${ }^{2}$ As a policy recommendation, communicative policy instruments can be used to inform parents about benefits and consequences of possible school choices. This way of policy making fits in the Dutch communicative governing traditions.
} 
support. He acted as the supervisor of Ms. Peters for her chapter on priority education and ethnic school segregation in The Netherlands.

\section{ACKNOWLEDGEMENT:}

None declared.

\section{CONFLICT OF INTEREST:}

None declared.

\section{REFERENCES}

[1] Heckmann F. Education and migration. Strategies for integrating migrant children in European schools and sccities. A synthesis of research findings for policy-makers. Bamberg: University of Bamberg; 2008 April.

[2] Muskens G, Peters D. Inclusion and education in European countries. Final report: 8. The Netherlands. Lepelstraat: DOCA Bureaus; 2009 August.

[3] STATLINE www.statline.cbs.nl. 2009 [retrieved 2009 June 08].

[4] Wolfgram P. Pupils, primary schools and their neighbourhood. A comparison of school populations in the 38 largest municipalities and their neighbourhood populations. Rotterdam: National Knowledge Centre for Mixed Schools; 2009 [In Dutch].

[5] Gijsberts M, Dagevos J. Removed of each others neighbourhood. The effect of ethnic concentration on integration and perception. The Hague: Social and Cultural Planning Office. 2005 [In Dutch].

[6] Gijsberts M. The decreasing effect of ethnic concentration on performance of pupils in primary education, 1988-2002. Sociologie 2006;2:157-77 [In Dutch].

[7] Overmaat M, Ledoux G. A search for success factors of black primary schools. Pedagogiek. 2001;21:359-71 [In Dutch].

[8] Tazelaar C, Joachim-Ruis A, Rutten J et al. The color of the school. Ethnical segregation in education. Houten/Diegem: Bohn Stafleu van Loghum; 1996 [In Dutch].

[9] Stanat P. School achievements of young people with migration background]. In: Baumert, Stanat, Watermann, Eds. Disparities related to immigration in education: differentiated educational processes and problems of equal justice. Wiesbaden: VS Verslag für Sozialwissenschaften; 2006. p. 189-219 [In German].

[10] Entorf H, Lauk M. Peer effects, social multipliers and migrants at school: an international comparison. Bonn: IZA 2006.

[11. Nordin M. Ethnic segregation and attainment in Sweden. Lund: Department of Economics, Lund University; 2006.

[12] Szulkin R, Jonsson JO. Ethnic segregation and educational outcomes in Swedish comprehensive schools: a multilevel analysis. Stockholm: Stockholm University Linnaeus Center for Integration Studies - SULCIS; 2007.

[13] Farley J. School integration and its consequences for social integration and educational opportunity. In: Heckmann F, Wolf R, Eds. Immigrant integration and education. The role of state and civil society in Germany and the US. Bamberg: efms; 2006. p. 5767.
[14] Driessen G, Doesborgh J, Ledoux G. Social integration in primary eduation. Amsterdam: SCO Kohnstamm Institute; 2003 [In Dutch].

[15] Muskens G. Inclusion and education in European countries. Final report: 2. Comparative conclusions. Lepelstraat: DOCA Bureaus; 2009 August.

[16] Allport G. The nature of prejudice. Cambridge, MA: AddisonWesley; 1954.

[17] Bakker J, Denessen E, Pelzer B, et al. Attitude towards class mates: ethnically colored? Education Research Days, Groningen 2007, June 06-08; Radboud Universiteit Nijmegen; 2007 p. 1-19 [In Dutch].

[18] Patterson JT. Brown v. Board of Education. A civil rights milestone and its troubled legacy. Oxford: Oxford University Press 2001.

[19] Pas G, Peters D. Black and white view on primary education. Towards local measures against ethnic segregation in primary education. Utrecht: Scientific Office Green Party; 2004 [In Dutch].

[20] Karsten S, Roeleveld J, Ledoux G, et al. School choice in a multiethnic society. Amsterdam: SCO-Kohnstamm Institute; 2002 [In Dutch].

[21] Education Council. Solid ground under the feet. Exploration of article 23 of the Constitution. The Hague: Education Council; 2002 [In Dutch].

[22] Lijphart A. The Politics of Accommodation: Pluralism and Democracy in the Netherlands. Berkeley: University of Califormia Press; 1968.

[23] Miedema S. The costs of pillarisation. Socialisme en Democratie. 1957;XIV (1) [In Dutch].

[24. Statistics Netherlands. Sixty years of statistics in time series. Zeist: De Haan; 1959 [In Dutch]

[25] Eurydice. The education system in The Netherlands 2007/08. http://eacea.ec.europa.eu/education/eurydice/documents/eurybase/e urybase_full_reports/NL_EN.pdf.; 2007 [retrieved 2009 June 27].

[26] Laemers M. Freedom of education; change in meaning and range. Nijmegen: ITS; 1999 [In Dutch].

[27] Rutten S, Peters D.Dispersion is no childrens' game. Analysis of success and failure factors in municipal policies concerning ethnic segregation in education. Highlights for dispersion and integration, appendix. The Hague: Education Council; 2005 [In Dutch].

[28] Peters D. Relegated to each other. An analysis of the open-ended approach to ethnic segregation in primary education. Enschede: University of Twente; 2006 [In Dutch].

[29] Ladd H, Fiske T, Ruijs N. Parental choice in the Netherlands: growing concerns about segregation. http://www.vanderbilt.edu/ schoolchoice/conference/papers/Ladd_COMPLETE.pdf; 2009 [retrieved 2009 June 27].

[30] Bergen C v, Leenen H v, Meer M v. Registration moment primary education. Amsterdam: Regioplan; 2007 [In Dutch].

[31] Parliament. Primary education 2008; [In Dutch].

[32] Municipality of Nymegen. Centralized registration for primary education Nymegen]. Nymegen: Municipality of Nymegen 2009; [In Dutch].

[33]. Walraven G. Choosing a (mixed) school in the neighbourhood? NRC Handelsblad. 2009; [In Dutch].

This is an open access article licensed under the terms of the Creative Commons Attribution Non-Commercial License (http://creativecommons.org/licenses/by-nc/ 3.0/) which permits unrestricted, non-commercial use, distribution and reproduction in any medium, provided the work is properly cited. 